AL IBTIDA: JURNAL PENDIDIKAN GURU MI (2021) Vol 8 (1) : 50-64

DOI: http://dx.doi.org/ 10.24235/al.ibtida.snj.v8i1.7092

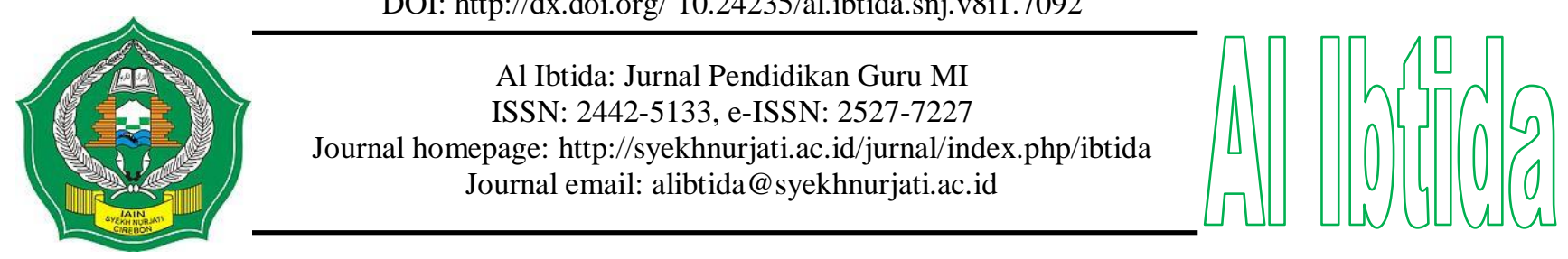

\title{
The Effectiveness of Kahoot! Based on Local Wisdom to Improve Creative Thinking Skill and the Spirit of Nationality of Students in Islamic Elementary School
}

\author{
E. Kus Eddy Sartono* \\ *Primary Education Department, Graduate School Program, \\ Universitas Negeri Yogyakarta, Indonesia \\ Email: kus_edisartono@uny.ac.id \\ Sukowati** \\ **Primary Education Department, Graduate School Program, \\ Universitas Negeri Yogyakarta, Indonesia \\ Email: sukowatiuny@gmail.com \\ Siti Soleha*** \\ ***Master of Teaching Chinese to Speakers of Other Languages Department, Faculty of International \\ School of Chinese Studies, Northeast Normal University, China \\ Email: sulixing217@gmail.com
}

Received: January 05 ${ }^{\text {th }}, 2021$. Accepted: June 02 ${ }^{\text {nd }}, 2021$. Published: June $27^{\text {th }}, 2021$.

\begin{abstract}
The goal of this research is to see how successful the Kahoot game! based on local wisdom is at boosting students' creative thinking capabilities and national spirit. This is a quasi-experimental study that uses technical data analysis, such as the t-test and MANOVA test, with SPSS as a supporting tool. Tests and questionnaires that had been validated by instrument specialists, class teachers, and peers were used to collect data. The participants in this study were fifth-grade students from an Islamic elementary school, with a total of 81 pupils. The results showed a significant level of $0.000<0.05$, indicating that fifth-grade students in a Islamic elementary school who are taught using the Kahoot game!! have a considerable comprehension of the ability to think about national characters compared to children who are not taught using the Kahoot game. The Kahoot! game based on local wisdom has a substantial impact on enhancing children's creative thinking skills and nationalism in Islamic elementary school, according to the findings.
\end{abstract}

Keywords: kahoot! game based on local wisdom, creative thinking skill, the spirit of nationality. 


\begin{abstract}
Abstrak
Penelitian ini bertujuan untuk mengetahui tingkat efektifitas game kahoot! berbasis kearifan lokal dalam meningkatkan kemampuan berpikir kreatif dan karakter semangat kebangsaan siswa. Penelitian ini merupakan penelitian quasi experiment dengan menggunakan teknis analisis data menggunakan uji t dan uji MANOVA dengan berbantuan SPSS. Pengumpulan data dilakukan melalui pretest-posttest dengan menggunakan tes dan angket yang telah divalidasi oleh ahli instrumen, guru kelas, dan teman sejawat. Subjek penelitian ini yaitu siswa kelas V madrasah ibtidaiyah yang berjumlah 81 siswa. Hasil penelitian yang diperoleh menunjukkan taraf signifikansi $0,000<0,05$ artinya ada perbedaan signifikan kemampuan berpikir kreatif dan karakter semangat kebangsaan siswa kelas $\mathrm{V}$ madrasah ibtidaiyah yang diajar menggunakan game kahoot! dan siswa yang tidak diajar dengan menggunakan game kahoot!. Sehingga dapat disimpulkan bahwa game kahoot! berbasis kearifan lokal berpengaruh signifikan dalam meningkatkan kemampuan berpikir kreatif dan semangat kebangsaan siswa di madrasah ibtidaiyah/sekolah dasar.
\end{abstract}

Kata kunci: game kahoot! berbasis kearifan lokal, keterampilan berpikir kreatif, semangat kebangsaan.

\title{
INTRODUCTION
}

One of the cognitive skills which should be possessed by students is creative thinking. The creative thinking skill is the ability to issue a new opinion (Boden \& Hart, 2018). Recently, the life of humans has entered the 4.0 industrial revolution era, where science and technology are developing quickly. In the industrial revolution era, four skills should be possessed, they are the way to think, the way to work, the tool for working, and the way to survive (Barak, 2017). One of those four skills that should be learned deeply in the $21^{\text {st }}$ century is the way of creative thinking (Trilling \& Fadel, 2009; Wrahatnolo, 2018).

Creative thinking skill is a compound and multidimensional concept that makes it difficult to be operationally defined (Desmita, 2012). The creative thinking skill in children is not only limited to the arts, but also in the meaningful learning activity (Nadjafikhah, Yaftian, \& Bakhshalizadeh, 2012; Samsudin, Setyadin, Suhendi, Chandra, 2017; Simonton, 2009). The creative thinking skill is an intellectual ability that is potential to produce original products which are social or personal, innovative, and related to science because it implements knowledge, skill, and scientific attitude (Demir, 2015; Hu \& Adey, 2002; Mukhopadhyay \& Sen, 2013).

The development of thinking skills is essential to be developed and taught in school. Seldom do the schools develop the thinking skills in students. Whereas, the thinking skill has big impacts on the problem-solving skill to solve daily life problems (Bono, 2007; Francesca, 2012; Maite \& Laura, 2011). The poor thinking skill quality of students can affect the quality of the input obtained by students. The experts of knowledge assume that the innovation in education is essentially depending on students' creative thinking (Rogers, 2019), that is why 
creating thinking skill should be early fostered in children (James, 2015; Munandar, 1987; Siew, Chong, 2014; Tan, 2009; Wright, 2010).

Besides developing cognitive skills, curriculum 2013 also develops character education. Madrasah Ibtidaiyah (Islamic Elementary School) as of formal education institution holds an essential role in transforming and internalizing attitudes and characters (Lickona, 2016). The reinforcement of character education is developed at every education level and becomes the responsibility of the related institution. One of the characters developed in elementary school is the character of nationality spirit (Kemendikbud, 2016). The spirit of nationality is still urgently needed since the lack of students' awareness to responsible towards their country (Damon, 2002).

The spirit of nationality indirectly has a correlation (affect and affected) with internal or external factors. It shows that the awareness and willingness of having the spirit of nationality are urgently needed. The spirit of nationality is urgently fostered to create and strengthen the characters early (Carter, 2011; Mustadi, 2011). In the curriculum of 2013, the value of nationality spirit can be internalized through the learning-based theme (Priyambodo, 2017) and it is accompanied by a program of school activities (Amri, Jauhari, Ahmad \& Elisah, 2011; Qodriyah, Hariyati \& Wangid, 2015). In addition, the character of the national spirit can also be instilled through simple games performed by the teacher by playing talking sticks, clapping hands, and using learning game applications (Rahmiati, Minawati, M. \& Handayani, 2020).

The importance of creative thinking skills and the spirit of students' nationality leads to the need for repair efforts. It is aimed to make students able to think creatively in solving various problems and fostering nationalism in students. In achieving that purpose, hardworking is essentially needed to make teachers able to help students in fostering creative thinking skills and the spirit of nationality (Kim, 2012; Meintjes \& Grosser, 2010; Weiping \& Baojun, 2013). The use of appropriate learning media can bridge the achievement of the goal (Anwar, Rasool, \& Haq, 2012; Maccagnano, 2007).

Kahoot! game based on local wisdom is one of the learning media tools in the form of online game which can be used to help students improving their creative thinking skill and the spirit of nationality (Arvyati, Ibrahim, 2015; Wang, 2015). The use of digital media refers to the strategy of visual media and audiovisual (Risabethe \& Astuti, 2017), so it emphasizes the coloring, pictures, components, music, and questions that can be used inside or outside the learning session whether in a group or individually (McGregor, 2007). It aims to facilitate students to learn while playing, control each other in solving the problems (Jančič \& Hus, 
2017; Naude, Bergh, and Kruger, 2014). Learning with peers will make students becomes easier to express their idea rather than to teachers. Playing with peers also makes students challenged to collect the points while thinking to be not left behind by other players.

Multimedia in the form of a Kahoot game! Which is presented in the form of images and words that make students more excited to learn (Mutlu-Bayraktar, Cosgun, \& Altan (2019). This Kahoot game can build knowledge through images and words. Thus, the use of the local wisdom-based game Kahoot! motivating students to understand the material. Through playful learning activities, creative ideas can be formed (Richardson \& Mishra, 2018). In addition, students are more interested in learning by using games (Christian et al., 2018).

Used the Kahoot game! based on local wisdom in student learning will also gain direct experience (Kozbelt, Beghetto, \& Runco, 2010). This is because there are interactive activities that occur by students with the media used, causing creativity in students (Maulia et al., 2017) the advantage of using interactive multimedia is to increase student interest and better understand the subject matter (Vrtačnik et al, 2000).

Learning using interactive multimedia in the form of the Kahoot game! It also allows students to focus and build active and cooperative learning (Ivers \& Baron, 2010). In learning, students will be happy and active if the learning material mixes verbal and visual information (Astuti \& Mustadi, 2014). So with a combination of material such as images, text, sound, and video which is packaged in multimedia, it will make it easier for students to understand the learning material that will be delivered by the teacher.

Previous studies related to increasing creative thinking abilities have been carried out by several researchers. The results of research conducted by Orhan Göksün \& Gürsoy (2019) showed that by using the game Kahoot! Student involvement in learning is increasing so that it can improve student learning outcomes which also have an impact on students' creative thinking skills. The research conducted by was conducted in three groups. Two groups acted as the experimental group and one group acted as the control group. The same thing was also shown in research conducted by Asikhia, Vora, Chandra, \& Myint (2017), the results of the study showed that learning by using the game Kahoot! helping students to be actively involved in class, encouraging students to be more active in participating in discussions, and increasing learning motivation. In addition, the results of this study also show that learning with the Kahoot game! be organized, fun, and interactive.

The results of the study Wang \& Tahir (2020) in the literature review are the effect of learning using the Kahoot game! can improve creative thinking skills and can have a positive 
effect on learning achievement, class dynamics, student and teacher attitudes, and reduce student anxiety. The results of previous research Wang (2015) also showed that the use of game response systems such as the game Kahoot! can improve students' creative thinking skills as shown by concentration, enthusiasm, and direct joy for teachers and students. Fernández-Vega et al (2020) in their research showed that learning with the Kahoot game! students are very receptive so that it increases their ability to think creatively. Average overall rating of using Kahoot games! is 8.4 points out of 10 or $76.61 \%$. Gözde Özaras Öz (2021) in his research also shows that students who learn to use the game Kahoot! have a higher average score than students who do not use the Kahoot game! in terms of creative thinking skills.

Because of the use of the Kahoot game learning media! Based on very important local wisdom, this study aims to see the effect of the application of games! Based on local wisdom on the ability to think creatively and the character of the national spirit of elementary school students through learning.

\section{METHODS}

This research belongs to the quantitative research with a quasi-experiment method. The research design is a nonequivalent pretest-posttest control group design (Creswell, 2012). The subjects in this study were the students of Madrasah Ibtidaiyah (Islamic elementary school) in the fifth grade at the district of Way Jepara, East Lampung, Indonesia. The samples of this study comprised 81 students taken by random sampling technique. Experiment class I consisted of 30 students and experiment class II consisted of 25 students with the game Kahoot! Based on local wisdom and control class consisting of 26 students with a conventional approach.

The Instrument used to collect the data consisted of the questions of creative thinking skills and the spirit of nationality. The questions of creative thinking skill test comprised 12 pre-test questions and 12 post-test questions. Creative thinking ability test questions consist of 12 pre-test questions and 12 post-test questions in the form of test descriptions. The test questions used in the pre-test and post-test include material related to national events during the colonial period. The material is contained in the theme of 7 events in life, sub-theme 1 of national events during the colonial period. Aspects that access the ability to think creatively include aspects of fluency, namely students can produce more than one answer, flexibility, namely students can produce answers from various points of view that are not following textbooks, authenticity, namely students can provide interesting answers, provide ideas, ideas, 
and the rationale for their way of thinking without imitating a friend's answer, and elaboration, namely students can describe answers in detail.

Meanwhile for the scale of nationality spirit consisted of 20 items which used Likert criteria scale 4 points with the scale 1 very often, 2 often, 3 sometimes, 4 seldom, and 5 never.. The indicators used on the scale of the national spirit include being willing to sacrifice, appreciating the history of the nation, loving the homeland and nation, accepting diversity, putting the public interest first, caring for the nation and state, and being proud of diverse cultures.

The creative thinking ability test is used to determine the effectiveness of Kahoot! based on local wisdom that is developed to increase students' creative thinking skills. The test of students' creative thinking abilities was conducted twice in each class, namely before learning activities through pre-test question processing activities and after learning activities by working on post-test questions. Giving pre-test and post-test questions are intended to determine the level of change in students' creative thinking abilities related to material on how to fill independence before and after learning activities are conducted in each class.

Moreover, the collected data thinking skill and the spirit of nationality was analyzed quantitatively by using SPSS 23. The researcher uses the Independent Sample t-Test (Sugiyono, 2016) to both know the effect of each variable, and measure the correlation between some independent variables and two or more dependent variables by using MANOVA (Hair, 2009).

\section{RESULTS AND DISCUSSION}

\section{The Results of Creative Thinking Skill Test}

The effectiveness of Kahoot! based on local wisdom can be seen from the hypothesis testing on the students' scores on the pretest and posttest of creative thinking skills. The following is a summary of the data on the value of the pre-test and post-test results of student's creative thinking skills in the fifth grade of Madrasah Ibtidaiyah (Islamic elementary school), both in the control class, experimental class I, and experimental class II.

Table 1. The Result of Pretest and Posttest of Creative Thinking Skill

\begin{tabular}{llllll}
\hline No. & Class & $\begin{array}{l}\text { Average Score } \\
\text { Pretest }\end{array}$ & Posttest & & Criteria \\
\hline 1 & Control & 52,53 & 63,98 & 0,23 & Low \\
2 & Experiment I & 54,11 & 84,26 & 0,56 & High \\
3 & Experiment II & 53,31 & 83,43 & 0,56 & High \\
\hline
\end{tabular}


Based on the table 1, it can be seen that the results of the pre-test scores of students' creative thinking abilities in the control class, experimental class I, and experimental class II have an increase in the post-test results. Based on the results of the pretest and posttest mean scores in the control class, it can be seen that there is an increase in the average score of 11.45 with a gain of 0.23 so that it can be categorized into moderate criteria. Whereas for the experimental class I obtained an average score of 30.15 with a gain value of 0.56 and the experimental class II obtained an average score of 30.12 with a gain value of 0.56 , which means that it can be categorized into high criteria.

Below is presented the results of the independent t-test for the variables of students' creative thinking skills in table 2 .

Table 2. T-test of Creative Thinking Skill

\begin{tabular}{llll}
\hline No. & Experiment Class & Significance Rate & Detail \\
\hline 1 & Experiment I & 0,000 & Ho is rejected \\
\cline { 2 - 2 } & Control & & \\
\hline 2 & Experiment II & 0,000 & Ho is rejected \\
& Control & \\
\hline
\end{tabular}

Based on the results of the independent t-test in table 2 above, it is known that the significance value of each test class is $0.000<0.05$. Thus, Ho is rejected and Ha, so it can be concluded that there are answers that can think creatively between students who take learning using the Kahoot game media! Based on local wisdom with students who do not take part in learning using the Kahoot game media! based on local wisdom.

\section{The Questionnaire Data of the Spirit of Nationality of Students}

The use of Kahoot! based on local wisdom aimed at improving students 'creative thinking skills regarding the material being studied as well as measuring the ability of students' nationality spirit. The measurement of students' perceptions of national spirit is measured through the activity of giving a scale of national spirit before learning activities (pretest) and after implementing the learning (posttest).

Table 3. Data of the Scale Result of Students' Nationality Spirit

\begin{tabular}{|c|c|c|c|c|c|}
\hline \multirow[t]{2}{*}{ No. } & \multirow[t]{2}{*}{ Class } & \multicolumn{2}{|c|}{ Average Scores } & \multirow[t]{2}{*}{ Gain } & \multirow[t]{2}{*}{ Criteria } \\
\hline & & Pretest & Posttest & & \\
\hline 1 & Control & 51,35 & 63,13 & 0,23 & Low \\
\hline 2 & Experiment I & 53,13 & 70,26 & 0,32 & Intermediate \\
\hline 3 & $\begin{array}{l}\text { Experiment } \\
\text { II }\end{array}$ & 53,75 & 75,60 & 0,41 & Intermediate \\
\hline
\end{tabular}

Based on table 3, it can be seen that there is a significant increase between the average pretest and posttest scores in experimental class I and experimental class II. The increase in the average pretest and posttest scores in the control class was not significant. The following 
shows the results of the independent t-test for the variables of the character of the student's love for the country in table 4 .

Table 4. T-test of Nationality Spirit Characters

\begin{tabular}{llll}
\hline No. & Experiment Class & Significance Rate & Detail \\
\hline \multirow{2}{*}{} & Experiment I & 0,000 & Ho is rejected \\
\cline { 2 - 2 } & Control & 0,000 & Ho is rejected \\
\cline { 2 - 2 } 2 & Experiment II & & \\
\hline
\end{tabular}

Based on table 4 of the data from the independent t-test results, the significance value of each test class shows a score of $0.000<0.05$. Thus Ho is rejected and Ha is accepted, so it can be concluded that there is a difference in the spirit of nationality between students who take part in learning using the Kahoot game media! based on local wisdom with students who do not take part in learning using the Kahoot game media! based on local wisdom.

\section{MANOVA Test in Creative Thinking Skill and the Character of Nationality Spirit}

The MANOVA test was conducted to see the effectiveness of the Kahoot! based on local wisdom in improving creative thinking skills and the character of the national spirit of students together. The MANOVA test was performed after the independent sample t-test was carried out. Below are presented the results of the MANOVA test in table 5.

Table 5. The Result of MANOVA Test

\begin{tabular}{llrrrrc}
\hline Effect & & Value & \multicolumn{1}{c}{ F } & Hypothesis df & Error df & Sig \\
\hline Intercept & Pillai's Trace & .998 & $21011.398^{\mathrm{b}}$ & 2.000 & 77.000 & .000 \\
& Wiks' Lambda & .002 & $21011.398^{\mathrm{b}}$ & 2.000 & 77.000 & .000 \\
& Hotelling's Trace & 545.751 & $21011.398^{\mathrm{b}}$ & 2.000 & 77.000 & .000 \\
& Roy's largest Root & 545.751 & $21011.398^{\mathrm{b}}$ & 2.000 & 77.000 & .000 \\
Kelas & .976 & 37.196 & 4.000 & 156.000 & .000 \\
& Pillai's Trace & .154 & $59.591^{\mathrm{b}}$ & 4.000 & 154.000 & .000 \\
& Wiks' Lambda & 4.645 & 88.256 & 4.000 & 152.000 & .000 \\
& Hotelling's Trace & 4.455 & $173.749^{\mathrm{c}}$ & 2.000 & 78.000 & .000 \\
\hline
\end{tabular}

Based on table 5, it can be seen that the significance value of the Hotelling's Trace test is less than $0.05(0.00<0.05)$, so the conclusion is that there is a significant difference in the ability to think creatively and the character of the national spirit of the fifth-grade elementary school students who use and do not use Kahoot! based on local wisdom. This conclusion also means that there is an influence from the game media Kahoot! based on local wisdom on creative thinking skills and the character of loving the country. Thus, it can be concluded that the game media is Kahoot! based on local wisdom can improve creative thinking skills and the character of the nationality spirit of students. 
E. Kus Eddy Sartono, Sukowati, Siti Soleha, The Effectiveness of Kahoot! Based on Local Wisdom...

\section{The Effectiveness of Kahoot! Based on Local Wisdom towards the Creative Thinking Skill and the Spirit of Nationality}

The ability to think creatively and the character of the national spirit are two aspects that the 21 st-century generation needs to have. Therefore, the ability to think creatively and the character of the national spirit need to be instilled in students. The implementation of the 2013 curriculum learning is supported by the existence of teaching materials, namely the 2013 curriculum book. Textbooks are one of the supports for the implementation of the 2013 curriculum. It is hoped that the 2013 curriculum book is not the only teaching material that is used as a reference in the teaching and learning process in the classroom. However, it is necessary to have other supporting media besides books to complement the 2013 curriculum textbook, namely the Kahoot! based on local wisdom.

The use of learning media (game) can improve creative thinking skills and the spirit of nationality (Nur, 2017). The ability to think creatively as referred to in this study is a mental activity carried out by students who are meant to solve problems, make decisions, and get an understanding of the learning process. The ability to think creatively has increased after students learn to use Kahoot! based on local wisdom.

The use of Kahoot! based on local wisdom for fifth-grade students is considered based on the theory put forward by Piaget. Jean Piaget revealed that fifth-grade elementary school students are aged 7-11 years and are in the concrete operational stage (Schunk, 2005). At the concrete operational stage, students' learning development cannot be invited to think abstractly, for that the presentation of abstract material is presented in concrete form. Likewise, the presentation of material on how to fill independence is presented in the form of an application that contains material and games accompanied by interesting illustrated images and videos. The goal is that students can find out things that can be done to fill independence appropriately. In addition, in high-class students are happy when teaching and learning activities involve students actively and directly in obtaining information (Allen \& Marotz, 2010).

Kahoot! based on local wisdom is interactive multimedia in the form of a game. Through the interactive media in the form of a game, students can play while playing through the learning materials and questions given in the form of quizzes. It is appropriate with Richardson \& Mishra (2018) who stated that the learning activities in the form of playing can trigger creative ideas. Christian et al (2018) also stated that students are more interested to learn using a game. 
Besides that, through the Kahoot game! based on local wisdom students will also gain firsthand experience. This is because there are interactive activities that occur by students with the media used. This is reinforced by the theory of the development of creativity which states that experience is related to the development of creative thinking (from the potential for achievement). Learning that frees students to develop independence and autonomy of thought will enable them to design creative ideas.

The learning materials are presented with illustrative pictures. Meanwhile, the game is conducted in the form of questions that are combined with text, images, or video to make students interested and show their creativity (Maulia et al., 2017). As Vrtačnik, et al (2000) stated, the advantage of using interactive media is that it can improve students' interest to learn and understand the lesson better.

The use of interactive multimedia in Kahoot! based on local wisdom combines some media such as text, images, video, and sound which are presented into one to make them more interesting, interactive, and containing the spirit of nationality. The combination of pictures, text, sound, and video will ease students to understand the learning materials so their creative thinking will improve (Noviani \& Wangid, 2018). In the learning, students will be happy and active if the learning materials given are a combination of verbal and visual information (Astuti \& Mustadi, 2014). The learning media which is a combination of audiovisual and verbal media will helps students to understand the learning materials and also will attract students' interest more (Ivers \& Baron, 2010).

Furthermore, according to the concept of neuroscience, the maximization of two brain hemispheres in learning can make students who can not only think orderly but also think divergently, globally, and creatively (Munawaroh, 2005). The left hemisphere is logicanalytic, convergent, and algorithmic, whereas the right hemisphere is divergent by more answer possibilities. When the right hemisphere is maximized in the learning process, it also means that teachers are developing students' creativity. The right hemisphere is influenced by intuition, imagination, music, and arts. Therefore, Kahoot! can be made as to the reference of learning source which supports students; creative thinking. The game does not present the questions directly, but it integrates them with pictures, video, or audio which support the development of students' imagination.

The students' creative thinking skill is improved if reviewed from the results of pretest and posttest. The learning using Kahoot! based on local wisdom experiences the higher improvement than the learning in the control class. The result of the t-test shows that there are significant differences in creative thinking and the spirit of the nationality of students who 
conduct the learning using Kahoot! based with the students who do not apply the product on local wisdom. The experimental class shows a higher improvement than the control class. Furthermore, Kahoot! based on local wisdom is more interesting for students in learning and it helps teachers to deliver the learning materials.

The use of Kahoot! based on local wisdom has a big contribution in improving students' creative thinking and the spirit of nationality. Besides, the use of Kahoot! based on local wisdom has beneficial in improving students' creative thinking skills (cognitive) and the spirit of nationality (affective). The use of media can improve the skills of cognitive, affective, and critical thinking (Wahyuningsih \& Mustadi, 2016).

Learning using interactive media allows students to focus and conduct active and cooperative learning (Ivers \& Baron, 2010). The learning using Kahoot! based on local wisdom can improve students' activeness in the class. Goldman \& Steele (2004) stated that interactive multimedia will make students more active in learning and students can analyze and synthesize well. Therefore, interesting learning will attract students' intention because they will never get bored in the class. Kahoot! based on local wisdom can also improve the spirit of nationality. The spirit of nationality in this case is the moral feeling of students when they are faced with the statements related to the spirit of nationality. It is in line with the theory stated by Lickona (2016), where the moral assessment can show moral feelings and vice versa.

The spirit of nationality in this study is the spirit of nationality in fulfilling independence. It is in line with what is stated by Mustari (2014) that nationalism education is essential to be taught to young generations by showing the pride and the love of homeland. One of the ways is by maintaining the ancestor's culture and appreciating what has been done by national heroes. Loving the local culture and appreciating the national heroes/heroines is an obligation that should be fostered by the young generations.

Students learn about the things related to nationalism through images, photos, video, or audio as audio-visual media. Furthermore, students combine the knowledge as the result of creative thinking. Then, students can imitate the spirit of nationality showed by Indonesia's independence warriors, the culture of Indonesia, and the activity in filling the independence. Therefore, after learning using Kahoot! based on local wisdom, the creative thinking skill and the spirit of nationality can be improved. So, Kahoot! based on local wisdom is effective in improving students' creative thinking and the spirit of the nationality of students in the fifthgrade elementary school. 


\section{CONCLUSION}

The results of this study show that the use of the Kahoot game based on local wisdom has a significant effect on increasing the ability to think creatively and the character of the national spirit of elementary school students. After intervention in the form of explicit teaching, creative thinking skills and the character of the national spirit of the students increased. The results of this study indicate that the use of Kahoot games based on local wisdom helps students have a sense of nationalism. This research is expected to contribute to the improvement of the learning process that aims to achieve learning objectives.

\section{REFERENCES}

Allen, K., E., \& Marotz, L., R. (2010). Profil Perkembangan Anak: Pra Kelahiran hingga Usia 12 Tahun. PT. Indeks.

Amri, S., Jauhari, A., \& Elisah, T. (2011). Implementasi Pendidikan Karakter dalam Pembelajaran: Strategi Analisis dan Pengembangan Karakter Siswa dalam Proses Pembelajaran. Prestasi Pustaka.

Anwar, M. N., Shamim-ur-Rasool, S. \& Haq, R. (2012). A Comparison of Creative Thinking Abilities of High and Low Achievers Secondary School Students. International Interdisciplinary Journal of Education, 1(1), 72-77.

Arvyati., Ibrahim, M., \& A. I. (2015). Effectivity of Peer Tutoring Learning to Increase Mathematical Creative Thinking Ability of Class XI IPA SMAN 3 Kendari 2014. International Journal of Education and Research, 3(1), 613-627.

Asikhia, I. S., Vora, A., Chandra, R., \& Myint, M. T. (2017). 2.41 Kahoot! A Colorful Musical Tool to Enhance Engagement for an Effective Prite Review Program. Journal of the American Academy of Child \& Adolescent Psychiatry, 56(10), S191. https://doi.org/10.1016/j.jaac.2017.09.121

Astuti, Y.W. \& Mustadi, A. (2014). Pengaruh Penggunaan Media Film Animasi terhadap Keterampilan Menulis Karangan Narasi Siswa Kelas V SD. Prima Edukasia, 2(2), 2562.

Barak, M. (2017). Science teacher education in the twenty-first century: a pedagogical framework for technology-integrated social constructivism. Research in Science Education, 47(2), 283-303.

Boden, G. M., \& Hart, L. (2018). Kahoot - Game Based Student Response System. Compass: Journal of Learning and Teaching, 11(1). https://doi.org/10.21100/compass.v11i1.668

Bono, E. (2007). Revolusi Berpikir. Kaifa.

Carter, S. (2011). On p urp ose: How great school cultures from strong character. Corwing A Sage Company.

Christian, I. V., Prasida, A. S., \& Edukasia, J. P. (2018). Developing Board Game as Learning Media about Waste Sorting for Fourth Grade Students of Elementary School. 6(1), 78-88.

Creswell, J. W. (2012). Educational research: Planning, conducting, and evaluating quantitative and qualitative research (4th ed.). Boston, MA: Pearson Education, Inc. 
Damon, W. (2002). Bringing in a new era in character education. Hoover Instution Press.

Demir, S. (2015). A study on the evaluation of scientific creativity among science teacher candidates. Research on Humanities and Social Sciences, 5(11).

Desmita. (2012). Psikologi Perkembangan Peserta Didik. Rosdakarya.

Fernández-Vega, I., Santos-Juanes Jiménez, J., \& Quirós, L. M. (2020). Use of Kahoot app to quantify the attention level of the student in the subject of Anatomical Pathology in Medicine and the assessment of the experience. Educacion Medica, xx, 1-5. https://doi.org/10.1016/j.edumed.2020.01.004

Francesca, G., \& A. D. (2012). The Dark Side of Creativity: Original Thinkers Can Be More Dishonest. Journal of Personality and Social Psychology, 102(3), 445-459.

Goldman, J.,D.,G. \& Steele, G., T. (2004). Multimedia Interactive Pedagogies on A CD-ROM for Teaching Primary School Children About the Human Body. Curriculum and Teaching, 19(1), 51-81.

Gözde Özaras Öz, Y. O. (2021). The effects of web based education and Kahoot usage in evaluation of the knowledge and skills regarding intramuscular injection among $\begin{array}{llll}\text { nursing students. } & \text { Nurse } & \text { Education }\end{array}$ https://doi.org/https://doi.org/10.1016/j.nedt.2021.104910

Hair, J. F. (2009). Multivariate data analysis.

Hu W., \& A. (2002). A scientific test international. Journal of Science Education, 24(1), 389404. https://doi.org/http://dx.doi.org/10.1080/09500690110098912

Ivers, K. S., \& Baron, A. E. (2010). Multimedia Project in Education Designing Producing and Assesing (4th ed). Abc. Clio. Llc.

James, M. A. (2015). Managing the classroom for creativity. Creative Education, 6(10), 1032-1043. https://doi.org/http://dx.doi.org/10.4236/ce.2015.610102

Jančič, P., \& Hus, V. (2017). Game-based learning in social studies classes in primary school. Proceedings of the 11th European Conference on Games Based Learning, ECGBL 2017, 285-293.

Kemendikbud. (2016). Permendikbud No. 22 tahun 2016 tentang standar proses pendidikan dasar dan menengah. Kemendikbud.

Kozbelt, A., Beghetto, R. A., \& Runco, M. A. (2010). Theories of creativity.

Kyung Hee Kim. (2012). The Creativity Crisis: The Decrease in Creative Thinking Scores on the Torrance Tests of Creative Thinking. Creativity Research Journal, 23(4), 285-295.

Lickona, T. (2016). Mendidik untuk Membentuk Karakter Bagaimana Sekolah dapat memberikan Pendidikan tentang Sikap Hormat dan Bertanggung Jawab. PT Bumi Aksara.

Maccagnano, A. (2007). Identifying and enhancing the strengths of gifted learners, $k$-8: easyto-use activities and lessons. Corwin Press.

Maite, G., \& Laura, B. (2011). Effects of a Play Program on Creative Thinking of Preschool Children. Journal of Psychology, 14, 1138-7416.

Maulia, R., Bernadi, A., \& Email, K. P. (2017). Peningkatan Kreativitas Siswa Kelas IV SD Melalui Pembelajaran Tematik- Integratif dengan Pendekatan Open-Ended Enhancing Creativity of Class IV SD Through Thematic Integrated Learning with Open-Ended Approac. Jurnal Prima Edukasia, 5(1), 91-101. 
McGregor, D. (2007). Developing thinking; developing learning: a guide to thinking skills in education. McGraw-Hill Education.

Meintjes, H., \& Grosser, M. (2010). Creative Thinking In Prospective Teachers: The Status Quo And The Impact Of Contextual Factors. Outh African Journal of Education, 30, 361-386.

Mukhopadhyay, R. \& Sen, M. K. (2013). Scientific creativity- a new emerging field of research: some considerations. International Journal of Education and Psychological Research, 2(1), 1-9. https://doi.org/http://ijepr.org/doc/v2- is1_jan13/ij1.pdf

Munandar, U. (1987). Mengembangkan bakat dan kreativitas anak sekolah. Gramedia.

Munawaroh, I. \& H. (2005). Neuroscience dalam pembelajaran. Majalah Ilmiah Pembelajaran, 1(1), 116-127.

Mustadi, A. (2011). Pendidikan karakter berwawasan sosiokultural (sociocultural based character education) di sekolah dasar, daerah istimewa yogyakarta (DIY). Dinamika Pendidikan, 20, 1-15.

Mustari, M. (2014). Nilai karakter refleksi untuk pendidikan. Ar-Ruzz Media.

Mutlu-Bayraktar, D., Cosgun, V., \& Altan, T. (2019). Cognitive load in multimedia learning environments: A systematic review. Computers \& Education, 141, 103618.

Nadjafikhah, M., Yaftian, N., \& Bakhshalizadeh, S. (2012). Mathematical creativity: some definitions and characteristics. Procedia-Social and Behavioral Sciences, 31, 285-291. https://doi.org/Behhttps://doi.org/10.1016/j.sbspro.2011.12.056

Naude, L., Bergh, T., and Kruger, I. (2014). Learning to like learning: An Appreciative Inquiry into Emotions in Education. Social Psychology of Education, 17(2), 211-228.

Noviani, S., \& Wangid, M. N. (2018). Developing Inquiry-Based Lectora Multimedia in Order to Increase the Logical Ability and the Creative Thinking. 6(1), 89-101.

Nur, A. (2017). Jurnal Prima Edukasia , 5 ( 1 ), 2017 , 1-10 Pengembangan Perangkat Pembelajaran Collaborative Learning Berbasis Kearifan Lokal untuk Meningkatkan Karakter Nasionalisme dan Kreatif Developing Collaborative Learning Kits Based on Local Wisdom to Improve Na. 5(1), 1-10.

Orhan Göksün, D., \& Gürsoy, G. (2019). Comparing success and engagement in gamified learning experiences via Kahoot and Quizizz. Computers and Education, 135, 15-29. https://doi.org/10.1016/j.compedu.2019.02.015

Priyambodo, A. B. (2017). Implementasi Pendidikan Karakter Semangat Kebangsaan Dan Cinta Tanah Air Pada Sekolah Berlatar Belakang Islam Di Kota Pasuruan. Jurnal Sains Psikolog, 6(1), 9-15.

Qodriyah, Sri Hariyati \& Wangid, M. N. (2015). Pengembangan SSP tematik integratif untuk membangun karakter kejujuran dan kepedulian siswa SD kelas II. Jurnal Prima Edukasia, 3(2), 177-189.

Rahmiati, R., Ninawati, M., \& Handayani, S. L. (2020). Pelatihan Menumbuhkan Karakter Siswa Sekolah Dasar Tanjung Sari Melalui Permainan Edukatif Sederhana. Jurnal SOLMA, 9(1), 231-238.

Richardson, C., \& Mishra, P. (2018). Learning environments that support student creativity: Developing the SCALE. Thinking Skills and Creativity, 27, 45-54. https://doi.org/10.1016/j.tsc.2017.11.004

Risabethe, A., \& Astuti, B. (2017). Pengembangan Media Pembelajaran Untuk Meningkatkan 
Motivasi Belajar Dan Karakter Semangat Kebangsaan Siswa Kelas V Sd. Jurnal Pendidikan Karakter, 7(1). https://doi.org/10.21831/jpk.v7i1.15498

Rogers, A. . (2019). Human behavior in the social environment perspectives on development and the life course fifth edition. Routledge.

Samsudin, Setyadin, Suhendi, Chandra, \& S. (2017). Seventh grade students' scientific creativity test: a preliminary-study on earth science 164 context. The 2nd Annual Applied Science and Engineering Conference, 288. https://doi.org/http://doi.org/10.1088/1757-899X/288/1/012012

Schunk, D. H. (2005). Commentary on self-regulation in school contexts. 15, 173-177. https://doi.org/10.1016/j.learninstruc.2005.04.013

Siew, N.M., Chong, C. L., \& C. K. O. (2014). Developing a scientific creativity test for fifth graders. Problems of Education in the 21st Century, 62, 109-123.

Simonton, D. K. (2009). Varieties of (scientific) creativity a hierarchical model of domainspecific disposition, development. Perspectives on Psychological Science, 4(5), 441452. https://doi.org/http://doi.org/10.1111/j.1745-6924.2009.01152.x

Sugiyono. (2016). Metode Penelitian Kombinasi. Bandung, Alfabeta

Tan, O. S. (2009). Problem based learning and creativity. Cencage Learning.

Trilling, B \& Fadel, C. (2009). 21st Century skills: Learning for life in our times. JosseyBass.

Vrtačnik, M., Sajovec, M., Dolničar, D., Pučko-Razdevsek, C., Glazar, A., \& Brouwer, N. Z. (2000). An interactive multimedia tutorial teaching unit and its effects on student perception and understanding of chemical concepts. Westminster Studies in Education, 23(1), 91-105.

Wahyuningsih, E., \& Mustadi, A. (2016). Pengembangan multimedia lectora pembelajaran tematik-integratif untuk peningkatan nilai karakter siswa kelas iv sekolah dasar. Jurnal Pendidikan Karakter, (1).

Wang, A. I. (2015). The wear out effect of a game-based student response system. Computers and Education, 82, 217-227. https://doi.org/10.1016/j.compedu.2014.11.004

Wang, A. I., \& Tahir, R. (2020). The effect of using Kahoot! for learning - A literature review. Computers and Education, 149(January), 103818. https://doi.org/10.1016/j.compedu.2020.103818

Weiping Hu., \& B. (2013). Increasing Studentse Scientific Creativity: The "Learn to Think" Intervention Program. The Journal of Creative Behavior, 47(1), 3-21.

Wrahatnolo, T. and M. (2018). 21st centuries skill implication on educational system. IOP Conference Series: Materials Science and Engineering 296. https://doi.org/doi:10.1088/1757-899X/296/1/012036

Wright, S. (2010). Understanding creativity in early childhood. Sage Publications. 